\title{
14. PETROLOGY OF VOLCANIC ROCKS RECOVERED ON DSDP LEG 19 FROM THE NORTH PACIFIC OCEAN AND THE BERING SEA
}

\author{
Richard J. Stewart, Department of Geological Sciences, University of Washington, Seattle, Washington \\ James H. Natland, Department of the Scripps Institution of Oceanography, University of California, \\ San Diego, La Jolla, California \\ and \\ William R. Glassley, Department of Geological Sciences, University of Washington, Seattle, Washington
}

\begin{abstract}
On Leg 19 of the Deep Sea Drilling Project, basaltic volcanic rocks were recovered from Site 183 in the western Gulf of Alaska, Site 191 on the floor of Kamchatka Basin, and Site 192 atop Meiji Guyot, the northernmost of the Emperor Seamounts.

At Site 183, alkali-olivine basalt was recovered underlying the thick sedimentary sequence of the Aleutian Abyssal Plain. The rocks strongly resemble Hawaiian alkali basalts, have high $\mathrm{K}, \mathrm{Sr}$, $\mathrm{Zr}$, and $\mathrm{Ba}$ contents, and may be associated with the formation of nearby Derickson Seamount. They are inferred to postdate the basement age estimated from magnetic anomalies and to be extrusive onto oceanic crust.

Tholeiitic basalt recovered at Site 191 beneath the sedimentary fill of Kamchatka Basin has low $\mathrm{K}_{2} \mathrm{O}, \mathrm{Ba}$, and $\mathrm{Sr}-87 / \mathrm{Sr}-86$ values similar to midocean ridge tholeiites, but has higher $\mathrm{Rb}, \mathrm{Sr}$, and $\mathrm{Zr}$ values which follow patterns established for other inter-arc basin basalts. The basalt is probably part of a regionally developed basaltic basement which may have intruded and enveloped older basin deposits in middle Oligocene time.

A series of at least five extrusive alkali basalt flows was recovered from near the crest of Meiji Guyot. The rocks are striking in having potassium feldspar cores in most plagioclase phenocrysts, and in their coarse grain size, reaching sub-gabbroic textures in some flow interiors. Theoretical and experimental data indicate the almost pure potassium feldspar could not crystallize in equilibrium with associated labradorite. Origin as xenocrysts derived from late-stage plutonic differentiation and later inclusion in basaltic lavas is not possible as glassy rinds containing no potassium feldspar xenocrysts. The mineralogy probably results from secondary replacement of calcic plagioclase cores by potassium-rich alkaline solutions produced during alteration of the basalts.
\end{abstract}

\section{INTRODUCTION}

Basaltic basement rocks were recovered from three sites on Leg 19, each of which was located in a different structural and tectonic setting within the North PacificBering Sea region (see Figure 1). Recovered material includes samples of alkali-olivine basalt from the Aleutian Abyssal Plain (Site 183); tholeiitic basalt from Kamchatka Basin, a back-arc marginal basin (Site 191); and alkali basalt from atop Meiji Guyot, the northernmost of the Emperor Seamounts (Site 192).

Relatively complete descriptions of megascopic features and the thin section petrography of rocks from each site are included in the respective site chapters. The purpose of this chapter is to summarize these descriptions, provide preliminary chemical and electron microprobe analyses, and interpret their petrology along with their lithologic, structural, and tectonic framework.
Additional studies on seismic velocity determinations by N.I. Christensen and magnetic properties by R.T. Merrill are reported in separate papers in this volume.

\section{RESPONSIBILITY AND ACKNOWLEDGMENTS}

The rocks discussed in this report were described on ship by Stewart and Natland. Additional thin section descriptions were done on shore by Stewart, microprobe analyses were done by Glassley, and X-ray mineralogic studies compiled by Natland. We are indebted to L. Shapiro, P. Elmore, R. Moore, H. Smith, J. Kelsey, and J. Glenn of the United States Geological Survey Rapid Rock Analysis Laboratory in Menlo Park, California, for major element geochemistry on three basalt samples, and to R. E. Mays of the same laboratory for minor element concentration data. Analytical work connected with isotopic age dating was performed by Teledyne Isotopes and was funded by a grant 


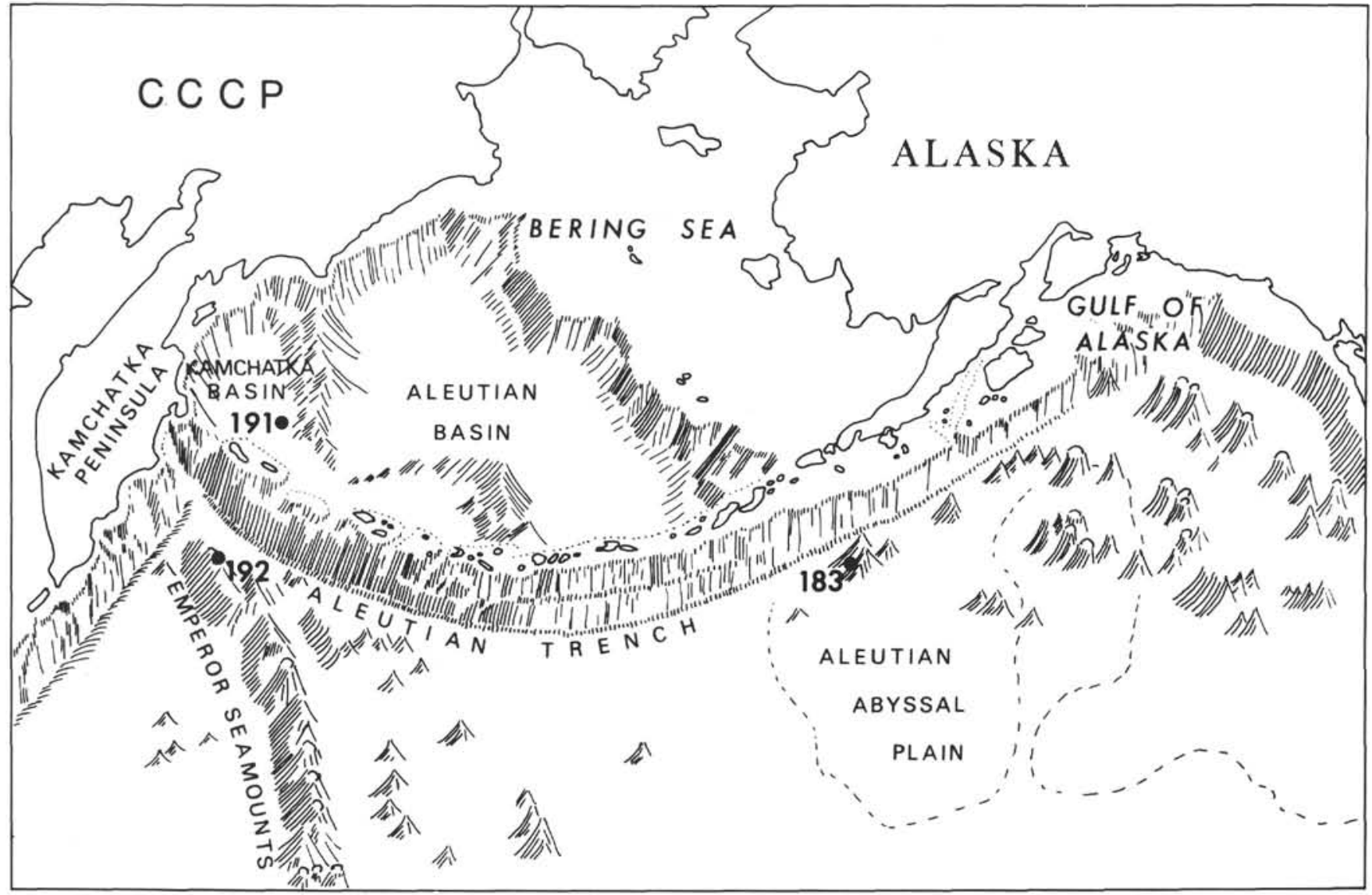

Figure 1. Topographic sketch map of the Aleutian Island Arc and adjacent portions of the North Pacific Ocean and Bering Sea. Site locations shown diagrammatically; for exact locations see respective site description chapters.

from the U.S. Geological Survey Office of Marine Geology, Pacific-Arctic Branch.

\section{GEOLOGIC SETTINGS}

Site 183 is located on the floor of the North Pacific Ocean near the northern edge of the Aleutian Abyssal Plain, in the western Gulf of Alaska (Figure 1). The location is approximately midway between anomalies 25 to the south and 24(?) to the north, as identified by Erickson and Grim (1969). The site lies about midway between Derickson and Sirius seamounts, and is about $15 \mathrm{~km}$ north of Seamap Channel, a fossil feeder channel for the sediments of the Aleutian Abyssal Plain (Hamilton, 1967 in press; Grim, 1969; Mammerickx, 1970). Overlying the basalt, in apparent stratigraphic succession, are turbidites of the Aleutian Abyssal Plain, a sequence in turn capped by a thick pelagic blanket (see Figure 2).

In contrast to Site 183, the basalt recovered at Site 191 is from the floor of Kamchatka Basin, a back-arc depositional trough lying north of the main Aleutian chain (Figure 1). Shirshov Ridge, a submerged north-southtrending mountain range, projects outward from Cape Olyutorskiy, eastern Siberia, and divides the deep-water region of the Bering Sea into Kamchatka Basin and the larger Aleutian Basin to the east. Throughout Kamchatka Basin, a rather rough, "oceanic-like" acoustic basement appears on seismic reflection records; the knoll at Site 191, part of this basement relief, appears to be depositionally draped by a palagic sequence, succeeded upward by Plio-Pleistocene turbidites (see Figure 2).

The most striking basalts recovered on Leg 19 were drilled at Site 192 near the summit of Meiji Guyot, the northwestmost of the Emperor Seamounts (Figure 1). The Emperor Seamounts extend north-northwesterly from west of Midway Island to the vicinity of the confluence of the Aleutian and Kuril trenches. Near its northwest terminus, the volcanic core of the chain loses its ruggedness because it is buried beneath as much as 1500 meters of topography-subduing deposits; even the summit area is mantled with as much as 1100 meters of sediments, dominantly mudstones (see Figure 2). Site 192 is located at the northwest end of the chain, at a water depth of 3000 meters, and over its sediment-mantled crest.

\section{NATURE OF EMPLACEMENT}

Although interpretations are hindered by incomplete recovery of material at the sediment-basalt interfaces of Sites 183 and 191, local and regional geologic considerations suggest that all three sites discussed in this report encountered normal extrusive basalt.

At Site 183 , recovery was limited to a few rounded pieces and chips of alkali-olivine basalt, and the critical 


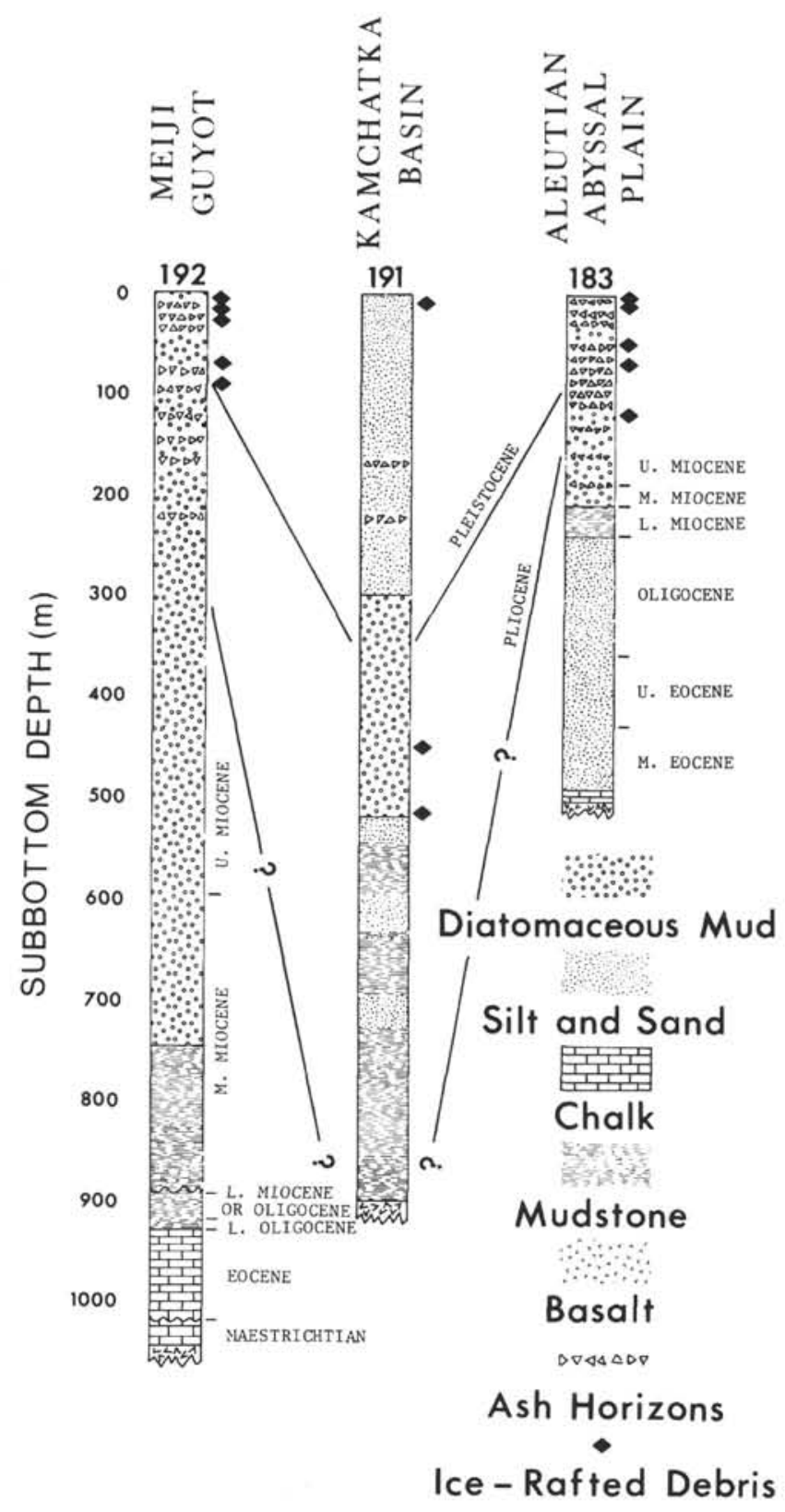

Figure 2. Generalized lithologic columns representing sediments and basaltic volcanic rocks penetrated on DSDP Leg 19, Sites 183, 191, and 192.

basalt-sediment contact was not continuously cored. Initial shipboard observation suggested the basalt was intrusive, based on the well-indurated, "baked" appearance of several pieces of limestone recovered above the basalt, and the presence of brown and orange marls above this. Such a suggestion was further strengthened by the pronounced 12 m.y. discrepancy between the age of the oldest overlying sediments (50 m.y.) and the age based on magnetic stratigraphy (62 m.y.; see Erickson and Grim, 1969, and Heirtzler and others, 1968).

However, mineralogic studies of the overlying sediments indicated they are not "baked", but rather are iron and manganese-rich sediments similar to those reported by several authors from the East Pacific Rise, and probably deposited at low temperatures directly from sea water (see Natland, this volume). Furthermore, evidence from Site 192 indicates that, during this period of the early Tertiary, sedimentation rates in the North Pacific were exceedingly low; thus sediments representing the 12 m.y. age discrepancy may be very thin and were simply washed through in coring operations. Also, the alkali basalts of Site 183 could well be related to the nearby seamounts; normal oceanic crust as old as predicted from the magnetic anomaly patterns could well underlie the alkali basalts.

At Site 191, the critical basalt-sediment interface again was not cored. However, plagioclase microlites in the basalt have a $\mathrm{K}-\mathrm{Ar}$ age of middle Oligocene age (approximately 30 m.y. See Table 3), which presumably means that the basalt is extrusive lava overlain unconformably by lower Pliocene or perhaps late Miocene mudstone. The gradational textural change observed from variolitic basalt downward to sub-diabasic basalt suggests that the margin of a flow or a large pillow was drilled. Variolitic textures commonly result from rapid freezing of basaltic liquids and are usually reported from the pillowed portions of submarine extrusions. However, variolitic textures have been reported from intrusive sills and even from pillows intrusive into soft marine sediments (Wilson, 1960; Garrison, 1972) and thus are unreliable indicators of underwater extrusion.

On a regional scale, the basalt layer underlying Kamchatka Basin does not give an impressive magnetic signature (see Figure 2, Site 191 report, this volume) and local intrusive-like peaks are associated with fairly weak (200-300 gammas) anomalies. Acoustic reflection records (see Figure 3, Site 191 report, this volume) demonstrate that the basalt layer encountered at Site 191 is regional in extent. It has a buried subsurface relief that can amount to as much as 800 meters in 10 to $12 \mathrm{~km}$, but typically is more subdued. The reflection records suggest that the basalt layer beneath Kamchatka Basin may be equivalent to the volcanic core of nearby Shirshov Ridge. These same records suggest that the relief of the basalt layer is depositionally draped by pelagic or hemipelagic deposits (Figure 2). Only locally, especially near the southern end of Shirshov Ridge, are there uplifted or deformed turbidite deposits indicating intrusive or diapiric relationships. The implication of these observations is that, except locally, the basalt layer beneath Kamchatka Basin is not intrusive into the overlying sedimentary section. This speculation also allows that the basalt may have intruded and overwhelmed older deposits, a possibility which is discussed in a later section (see also Scholl and Creager, cruise leg synthesis, this volume).

Atop Meiji Guyot at Site 192, geologic relations clearly indicate that a sequence of five or more extrusive alkali basalt flows totalling 11-3/4 meters was penetrated. In the recovered core, zones containing glass, fine-grained basalt, and abundant vesicles and amygdules are gradational downward to coarse-grained diabase. Five major repetitions of this sequence downward from the basalt-sediment interface suggest that a series of basalt flows was encountered, each having fine-grained vesicular tops and coarse-grained diabasic interiors. The rocks are extensively fractured, particularly at the base of each flow, and calcite, 


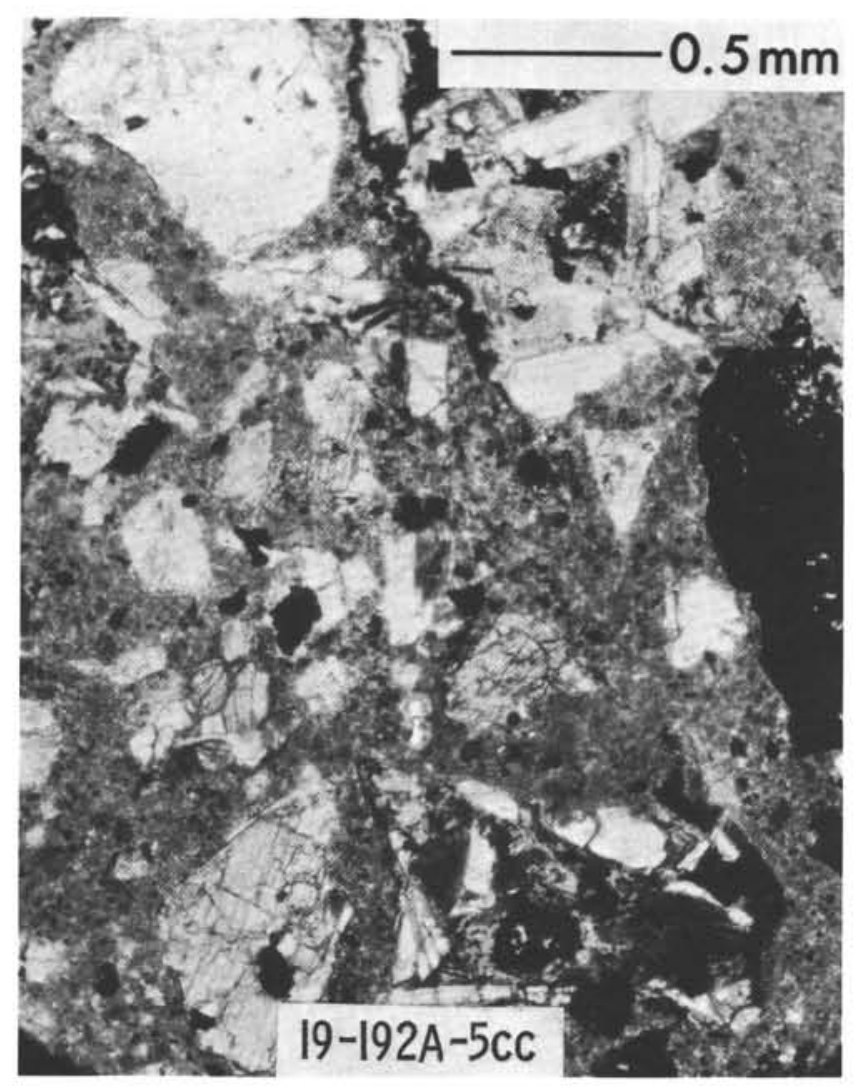

Figure 3. Basaltic sand with micrite matrix filling fracture in diabasic basalt on Meiji Guyot. 19-192A-5(CC).

nannofossil limestone, basaltic sands, and red brown iron oxides fill the cracks (Figure 3). Sharp repetitious variations from glassy or variolitic basalt to diabasic basalt in the upper 2 meters suggest the presence of pillows and pillow margins. Sediments immediately above the sediment-basalt contact contain unrecrystallized nannofossils, and apparently are not metamorphosed.

\section{THIN-SECTION MINERALOGY AND TEXTURES}

The basalts recovered from Sites 183, 191, and 192 are all markedly different rocks, with those from Site 192 being particularly unique in terms of mineralogy and textures.

The basalt recovered from beneath the Aleutian Abyssal Plain at Site 183 is an alkali olivine basalt. Except in glassy zones (Figures 4 and 5), euhedral olivine phenocrysts $\left(\mathrm{Fo}_{80}\right)$ are altered, most grains having thin iddingsite rims, some with serpentine cores. Partial resorption of most phenocrysts is indicated by abundant embayed boundaries. Groundmass olivine quench crystals (Figure 6) form about 20 percent of the rock and are largely altered to iddingsite. Clear groundmass pyroxenes display variolitic textures (Figure 6), with feathery crystals up to $0.5 \mathrm{~mm}$ long. Nontronite and calcite replace some former glass zones, and fill locally abundant vesicles. Palagonite bands and zeolite- and pyrite-filled veinlets extensively cut the glassy rind (Figure 4).

The basalt recovered from Kamchatka Basin, Site 191, is mostly pyroxene-plagioclase tholeiitic basalt, grading

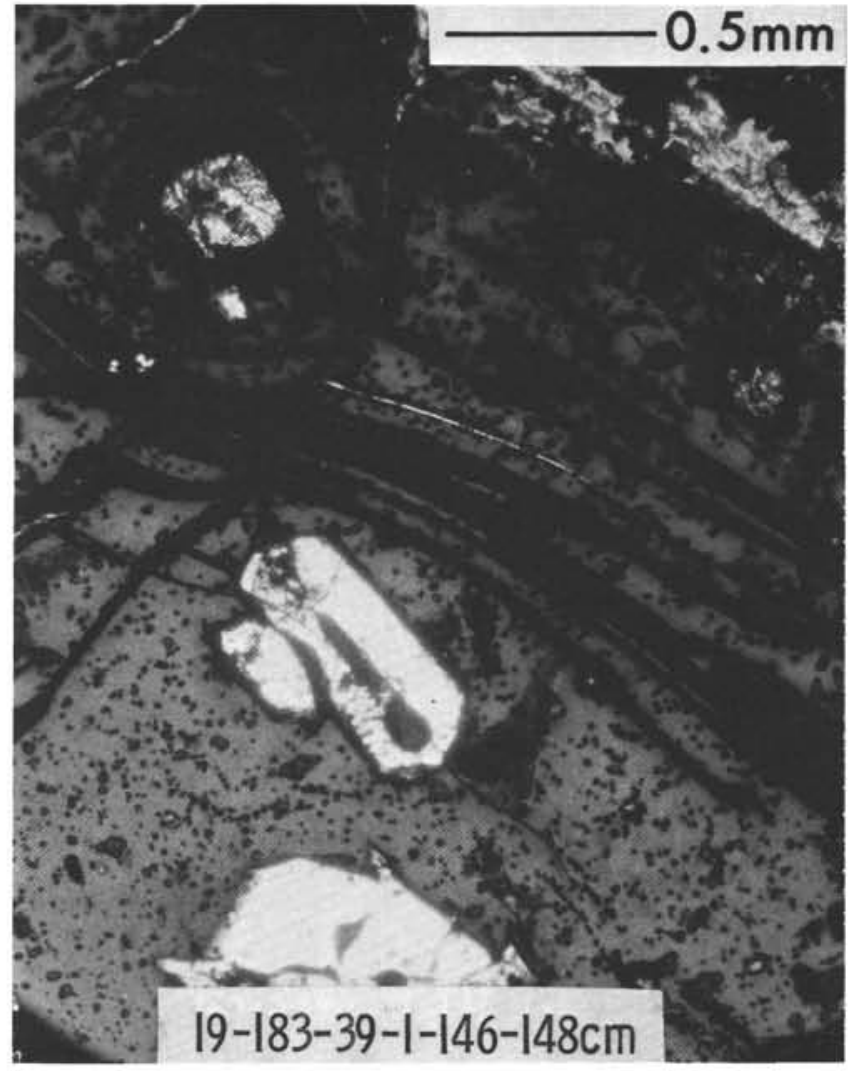

Figure 4. Vitrophyric rind on variolitic basalt underlying the Aleutian Abyssal Plain. Euhedral olivine phenocrysts with brown basalt glass inclusions set in matrix of brown basalt glass. Small flecks are pyroxene microcrysts black bands are opaque zones. Anhedral olivine phenocryst in upper left is altered to serpentine with rim of iddingsite. Dark area in upper right is orange palagonite cut by a vein of zeolite. 19-183-39-1(146-148 cm).

downward in the 1.4 meters of recovered material to sub-diabasic basalt. Plagioclase is coarse and acicular to lathy, forming radial clusters in the variolitic portions (Figure 7), and glomeroporphyritic clots in the sub-diabasic rock. Typical phenocryst compositions are $\mathrm{An}_{70}$ to $\mathrm{An}_{75}$ (from Carlsbad-albite twins). Augite is subophitic, clear or pale brown but clouded with opaques, and displays local herringbone structure. Magnetite is ubiquitous.

Much of the plagioclase in Site 191 basalt shows incipient alteration. Deep green patches of nontronite apparently replace former glassy areas, and sericite(?) and carbonate are also present. Nontronite and chlorite-filled amygdules were present in all examined thin sections. The degree of alteration apparently decreases downward, as the least altered rock is the subdiabasic basalt at the bottom of Core 16.

The alkali basalts from Meiji Guyot, Site 192, are pyroxene-plagioclase basalt flows, with glassy and variolitic margins and coarse, diabasic interiors (Figures 8 and 9). In glassy zones, euhedral clinopyroxenes, rare pseudomorphs of iddingsite after olivine, and labradorite or andesine crystals form phenocrysts floating in basalt glass darkened by iron oxides (reddish in reflected light). Towards the 


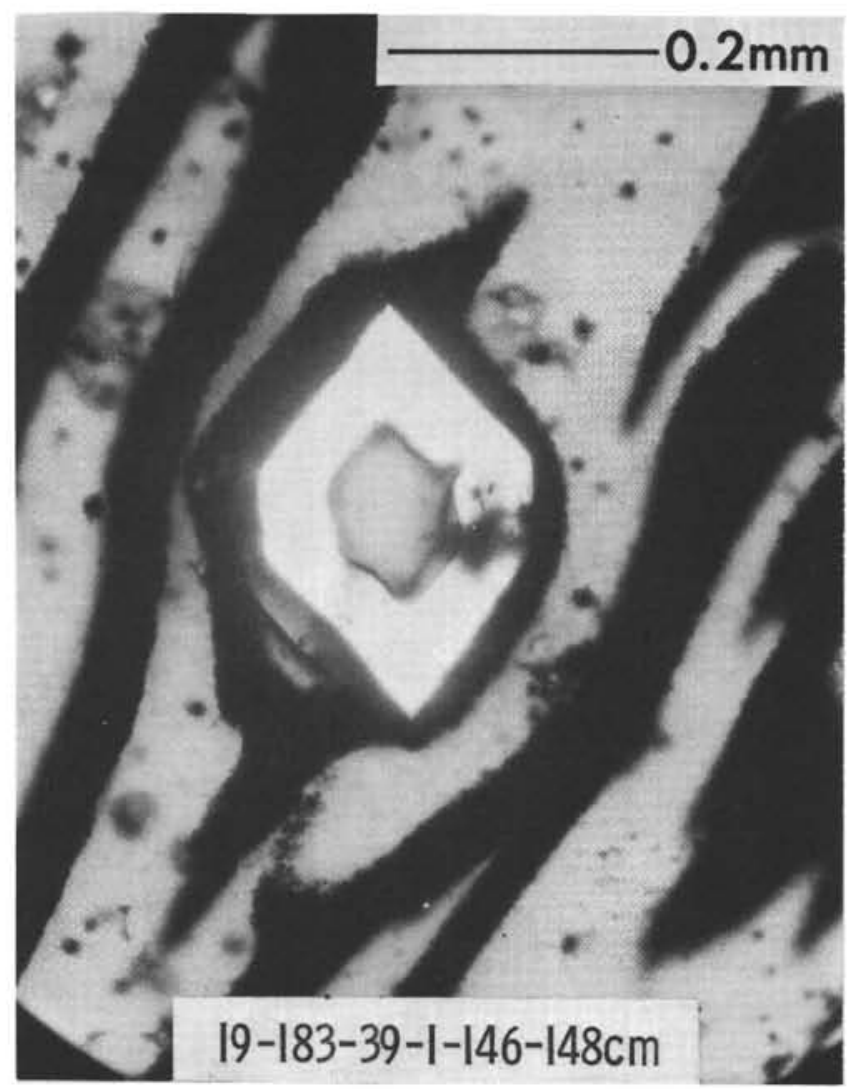

Figure 5. Euhedral olivine phenocryst enclosing core of brown basalt glass and set in vitrophyric matrix of brown glass. Dark areas are bands of opaques, small flecks are pyroxene microcrysts. 183-39-1(146-148 cm).

interior of the flows, glass is superseded by variolitic clinopyroxenes and acicular labradorite or andesine needles which occupy space between the plagioclase and clinopyroxene phenocrysts. In the coarsest-grained flow interiors, textures range from diabasic to sub-gabbroic, with most grains euhedral to subhedral in outline. Synneusis aggregates (Vance, 1969) of plagioclase or clinopyroxene crystals are common in all textural variations. Opaques include magnetite and hematite. Fractures(?) are filled with calcite, nannofossil limestone, basaltic sands, and red brown iron oxides.

Alteration is pronounced in Site 192 volcanics; up to 40 percent of a given section may be green nontronite, chlorite, or calcite. Abundant growth of secondary nontronite lends a greenish color to the entire core. Vesicles are filled with montmorillonite, nontronite, iron oxides (usually goethite), and calcite.

Curiously, in the variolitic and diabasic portions, calcic cores of most plagioclases are apparently replaced by secondary potassium feldspar (sanidine) (Figures 8, 9, 10, 11). Textural evidence favoring secondary replacement rather than primary magmatic or xenocryst origin for the potassium feldspars consists of (1) normally irregular boundaries between usually interdigitating potassic cores and labradorite borders, with selvages of plagioclase floating in potassium feldspar and (2) total lack of potassium

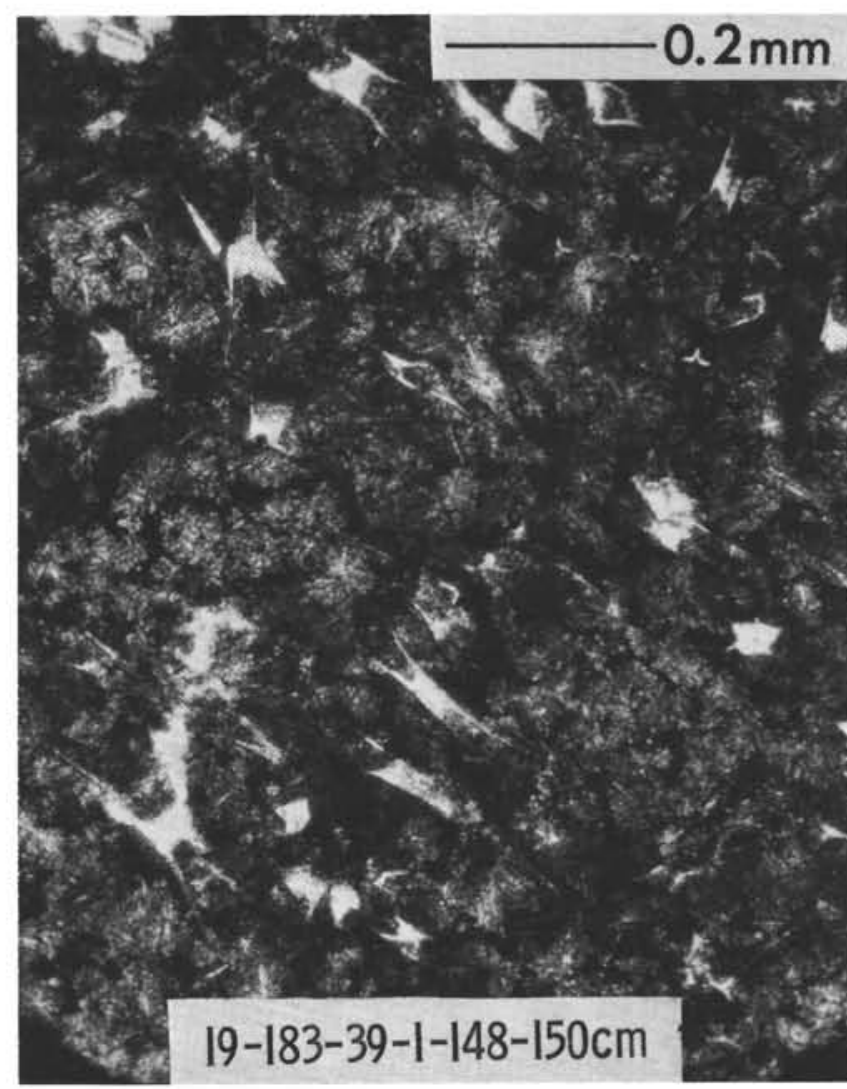

Figure 6. Variolitic texture in pyroxenes and altered, doubly swallow-tailed quench crystals of olivine in olivine basalt underlying Aleutian Abyssal Plain. $19-183-39-1(148-150 \mathrm{~cm})$.

feldspar cores in otherwise identical phenocrysts floating in glassy zones. In these zones, the cores, if present, are calcic plagioclase.

\section{GEOCHEMISTRY AND MINERALOGY}

One sample from each of the three sites was analyzed. Methods used were those described in U.S. Geological Survey Bulletin 1144A, supplemented by atomic absorption. Minor elements were analyzed by quantitative spectrographic techniques. Additional $\mathrm{Rb}$ and $\mathrm{Sr}$ concentration data were obtained by Teledyne, Inc. All analyses are listed in Table 1, along with CIPW norms and modes calculated for each sample.

Quantitative analyses of the main silicate phases in the basalts were obtained by electron microprobe techniques, the results of which are listed in Table 2 . All analyses were conducted on an Applied Research Laboratories EMX-SM five-channel instrument using an accelerating potential of $15 \mathrm{kv}$ and sample current of $0.07 \mu$ amps. Standards employed included a suite of analyzed natural olivines, clinopyroxenes, feldspars, and synthetic silicate glasses. Corrections for deadtime, drift, and background were applied to all analyses; corrections for fluorescence, absorption and mean atomic number were applied to the feldspar analyses by use of a standard computer program. These latter corrections were not applied to the pyroxene 


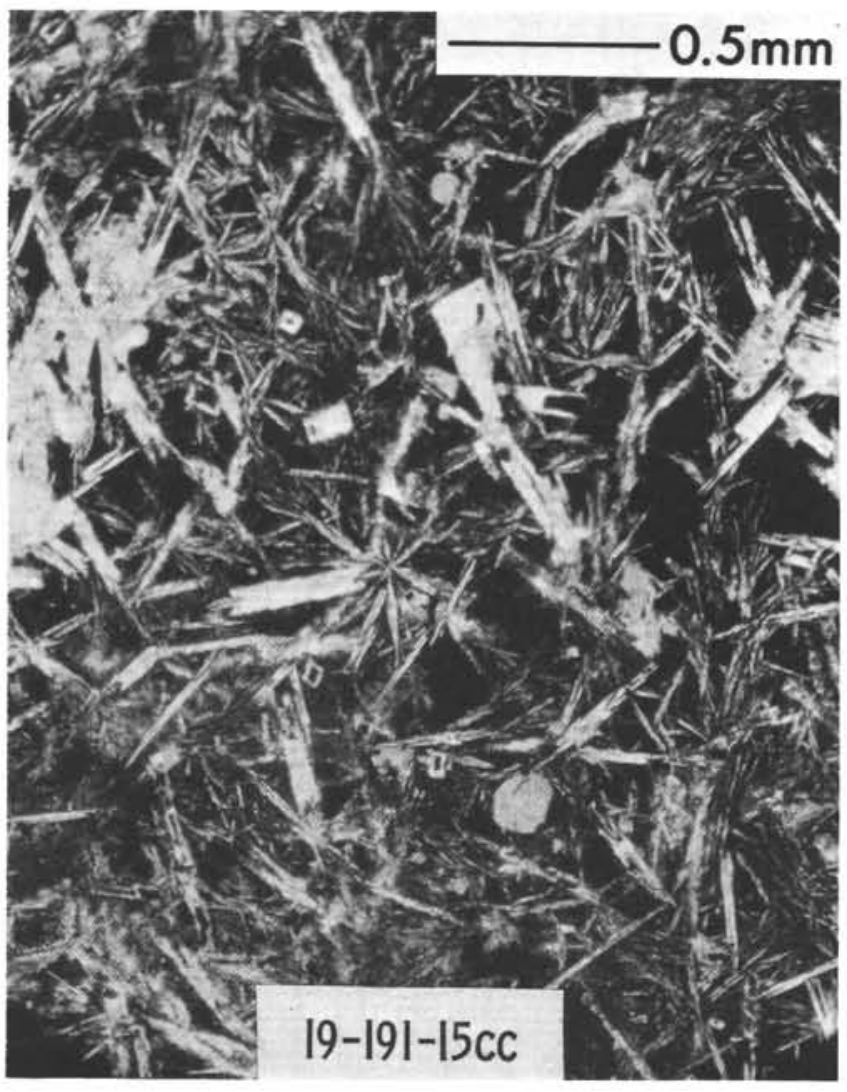

Figure 7. Variolitic pyroxene-plagioclase basalt underlying Kamchatka Basin. Radiating acicular feldspar crystals in matrix of pyroxene and opaques. Oval areas are vesicles or former intersertal glass now filled or replaced with nontronite; dark patches are pyroxenes clouded by opaque inclusions. 19-191-15(CC).

and olivine analyses as the standards used were very similar to the unknowns.

\section{Site 183}

When compared with published analyses of basaltic rocks, the sample from Site 183 is strikingly similar to Hawaiian alkalic basalts. In the nomenclature of MacDonald and Katsura (1964), it is an alkalic olivine basalt (Figure 2), which falls exactly on the trend of the Hawaiian alkalic suite (Figure 13). In addition, the $\mathrm{Sr}, \mathrm{Zr}$, and $\mathrm{Ba}$ values are typical of mildly alkaline Hawaiian basalts (Engel and others, 1965; Hubbard, 1969; see Figure 4). Also, when plotted on a normative nepheline-plagioclase olivine diagram, it falls within the field of East Pacific Rise-Juan de Fuca Ridge seamounts, but outside the compositional range for Mid-Atlantic Ridge Seamounts (Bass, 1971; see Figure 15). The unusually high $\mathrm{Cr}$ and $\mathrm{Ni}$ contents, though divergent from the average alkalic basalt, can be explained on the basis of the abundant olivine phenocrysts and microphenocrysts in this sample.

Olivine in two samples from Site 183 are chrysolite $\left(\mathrm{Fa}_{20}\right)$ and are slightly zoned. The zoning is not parallel to the present crystal morphology, probably as a result of crystal resorption due to disequilibrium with the melt. Semiquantitative analyses of minute clinopyroxene grains

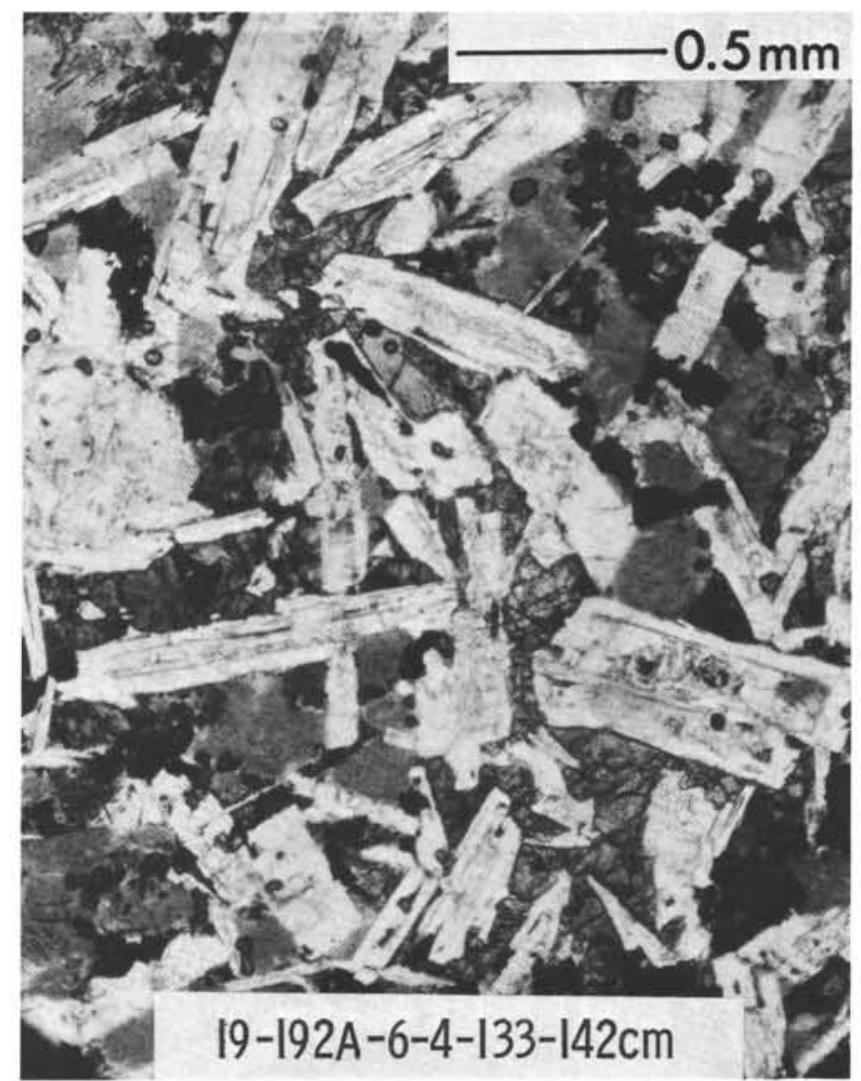

Figure 8. Typical diabasic texture in alkali basalt from Meiji Seamount. Stubby plagioclase laths have potassium feldspar cores. Pyroxene is subophitic. Darkest areas are opaques, light gray areas are nontronite replacements of glass. 19-192A-6-4(133-142 cm).

coexisting with the olivines indicate they are augite. Small grain size precluded quantitative analysis.

Site 191

Basalt from Site 191 is tholeiitic, falling in the high-alumina basalt field of Kuno $(1960,1968)$ on the total alkalies-silica diagram (Figure 2), and plots in the field of plagioclase tholeiites on a normative plagioclaseolivine-pyroxene diagram (Figure 16), and outside the field of mid-ocean ridge basalts on a normative plagioclaseolivine-hypersthene diagram (Figure 15). $\mathrm{K}_{2} \mathrm{O}, \mathrm{Ba}$, and Sr87/86 concentrations fall within the range of values consistently found in mid-ocean ridge tholeiites (Bass, 1971), but the $\mathrm{Ni}$ content is too low. The $\mathrm{Rb}, \mathrm{Sr}$, and $\mathrm{Zr}$ values are greater than those usually encountered in ridge tholeiites, and are similar in all respects to inter-arc basin tholeiites described by Hart and others (1972). High alumina basalts were also among a suite of basalts reported from the Lau Basin, dredged from an inter-arc basin zone of crustal dilation (Sclater and others, 1971).

Plagioclases in samples from Site 191 vary in composition from $\mathrm{An}_{70}$ to $\mathrm{An}_{60}$, the greatest variation occurring between crystals rather than in zoning within grains. Clinopyroxenes in the samples again are too small for accurate quantitative analysis. 


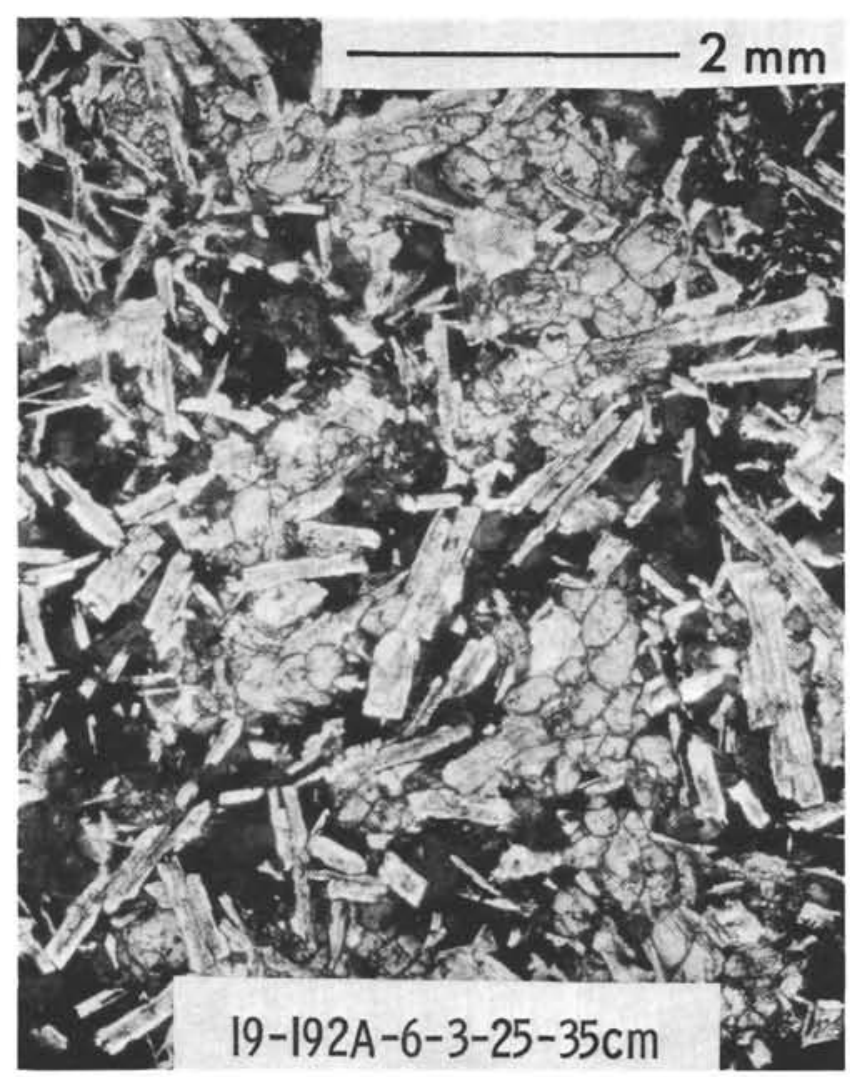

Figure 9. Sub-gabbroic texture in alkali basalt from Meiji Guyot. Stubby plagioclase laths with potassium feldspar cores, and intergranular cumulate(?) pyroxenes. Darkest areas are opaques, dark gray areas are green blebs of nontronite replacing interstitial glass. 19-192A-6-3$(25-35 \mathrm{~cm})$.

\section{Site 192}

The pervasive intense alteration of the Site 192 basalt makes its chemical or normative classification somewhat ambiguous. The rock analyzed falls in the alkali basalt field on an alkalies-silica diagram (Figure 12), but on a normative basis is an olivine tholeiite (Figure 16) and falls in the field of several oceanic tholeiite suites defined by Bass (1971) (see Figure 15). Trace element concentrations resemble those of Hawaiian tholeiites (Engel and others, 1965; Hubbard, 1969; see Figure 14).

Mineralogically, the basalts resemble various alkalic suites. In all four samples analyzed by microprobe, the clinopyroxenes are homogenous salites only occasionally slightly zoned, with $\mathrm{Fe}$ increasing and $\mathrm{Mg}$ decreasing away from crystal cores. The range of composition is slight, as shown on Figure 17, a Wo-En-Fs diagram. Plotted on the diagram are trend lines for pyroxenes of various alkalic suites, plus the Skaergaard tholeiitic series. The Site 192 pyroxenes are considerably more calcic than those of the other series plotted. Calcic pyroxenes typify the alkalic series on the island of Maui, Hawaii, as demonstrated by Fodor and Bunch (1972). Tholeiitic basalts from Maui contain pigeonite and augite (in the range Wo30-40). Pyroxenes of the alkali basalt-trachyte series are augites and

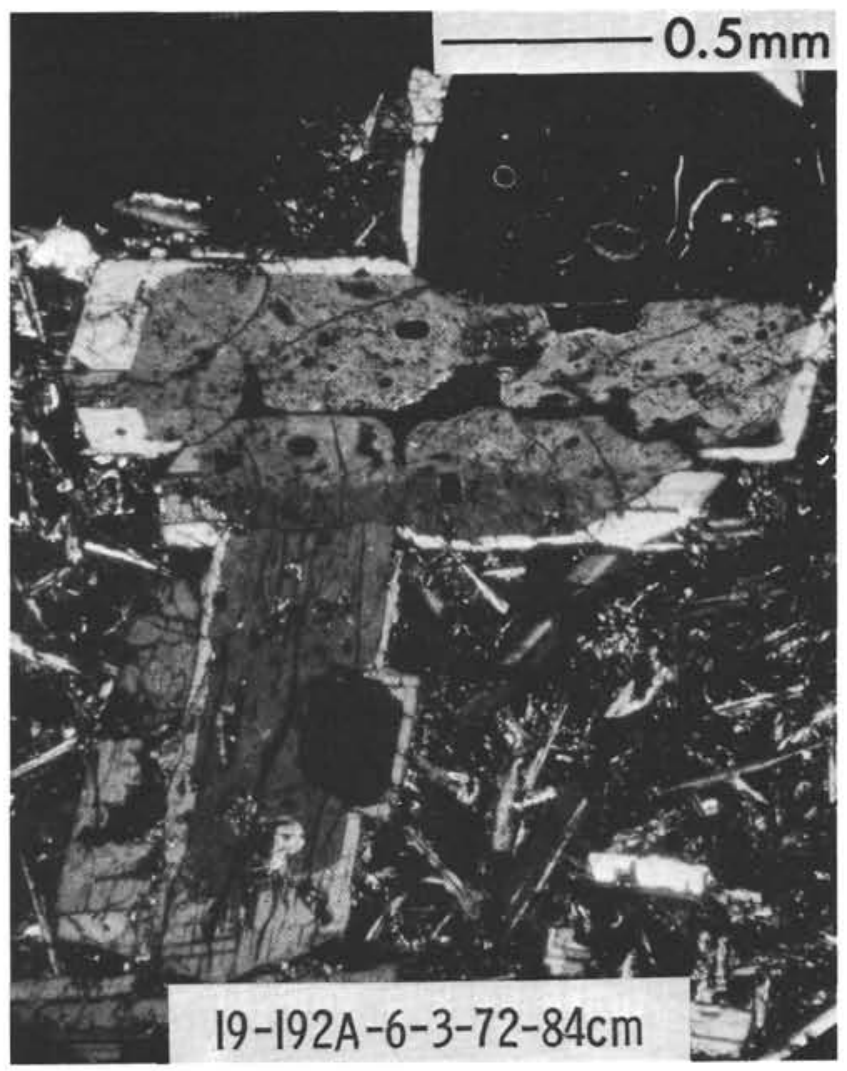

Figure 10. Detail of calcic core of large phenocryst replaced by potassium feldspar in basalt from Meiji Guyot. Sharp outlines typical for large phenocrysts, atypical for smaller crystals. X-nicols. 19-192A-6-3$(72-74 \mathrm{~cm})$.

salites with Wo38-48. Pyroxenes from trachytes are richer in iron ( $\left.\mathrm{Fs}_{22-30}\right)$ than hawaiites and mugearites ( $\left.\mathrm{Fs}_{14-20}\right)$. On this basis some of the Site 192 pyroxenes resemble those from Maui trachytes. Groundmass pyroxenes in the Site 192 rocks are quite variable, usually higher in $\mathrm{FeO}$, $\mathrm{MnO}, \mathrm{TiO}_{2}$, and $\mathrm{MgO}$ than the phenocrysts.

Phenocryst plagioclase in the Site 192 samples ranges from $\mathrm{An}_{70}$ to $\mathrm{An}_{50}$ and shows both normal and oscillatory zoning. Groundmass laths range from $\mathrm{An}_{55}$ to $\mathrm{An}_{30}$ in composition usually normally zoned. Such sodic groundmass plagioclase is not typically found in tholeiitic basalts as evidenced by the Site 191 feldspars. Many plagioclase phenocrysts and microphenocrysts at Site 192 contain potassium feldspar (sanidine) cores, compositionally 99 percent orthoclase, with only trace amounts of $\mathrm{Na}_{2} \mathrm{O}$ and $\mathrm{CaO}$ detected. All analyzed crystals are very homogeneous and there is no observed compositional variation between grains.

\section{DISCUSSION}

The chemistry and mineralogy of the basalt from Site 183 so resemble alkalic basalts from seamounts and the Hawaiian Islands that a similar genetic origin must be considered. Although the seismic profile does not show a 


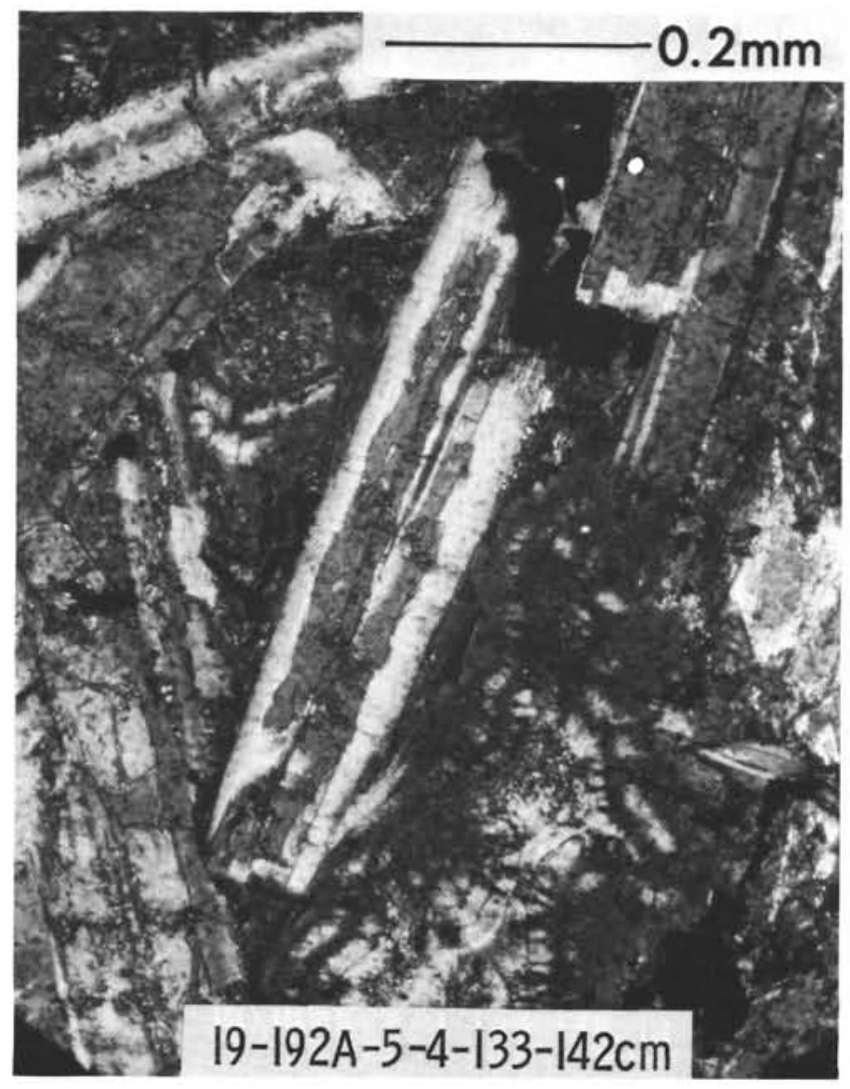

Figure 11. Typical replacement textures in lathy plagioclase fledspars, Meiji Guyot basalts. Note irregular boundaries and selvages of plagioclase extending into replacement core of potassium feldspar. $X$-nicols. $19-192 A-5-4(133-142 \mathrm{~cm})$.

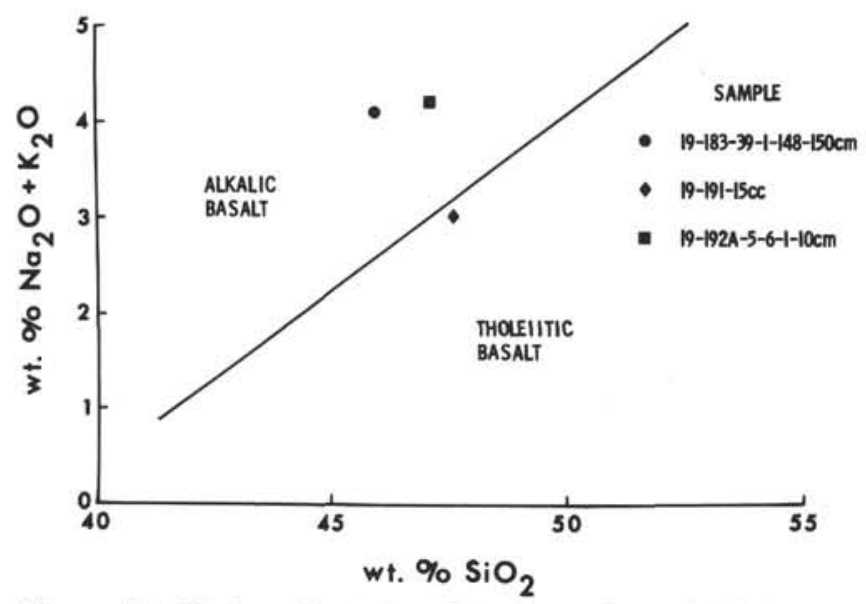

Figure 12. Harker Variation Diagram of total alkalies vs. silica showing relation of DSDP Leg 19 basalts. Fields of alkalic and tholeiitic basalt from Macdonald and Katsura (1964).

basement high at the site (Chapter 2, this volume), buried basement projections and exposed seamounts against which turbidites of the Aleutian Abyssal Plain are truncated are common in the area (Hamilton, 1967). It seems reasonably possible that Site 183 tapped an extreme flank of a seamount, perhaps nearby Derickson or Sirius. This

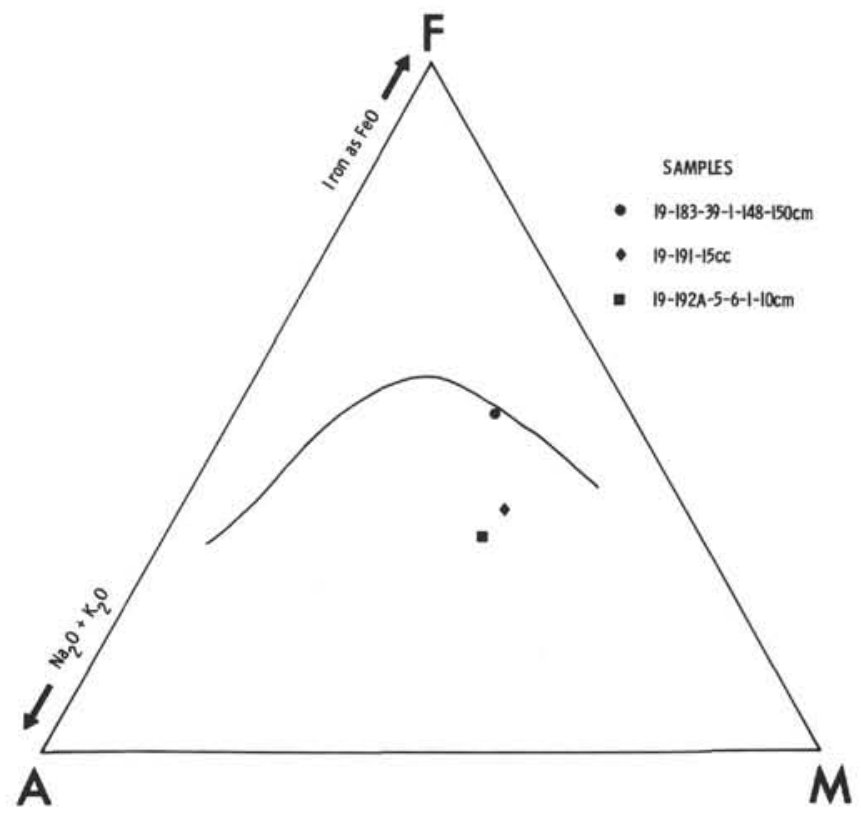

Figure 13. A-F-M diagram showing relation of rocks recovered on Leg 19 to differentiation trend of Hawaiian alkalic basalts (after Macdonald and Katsura, 1964).

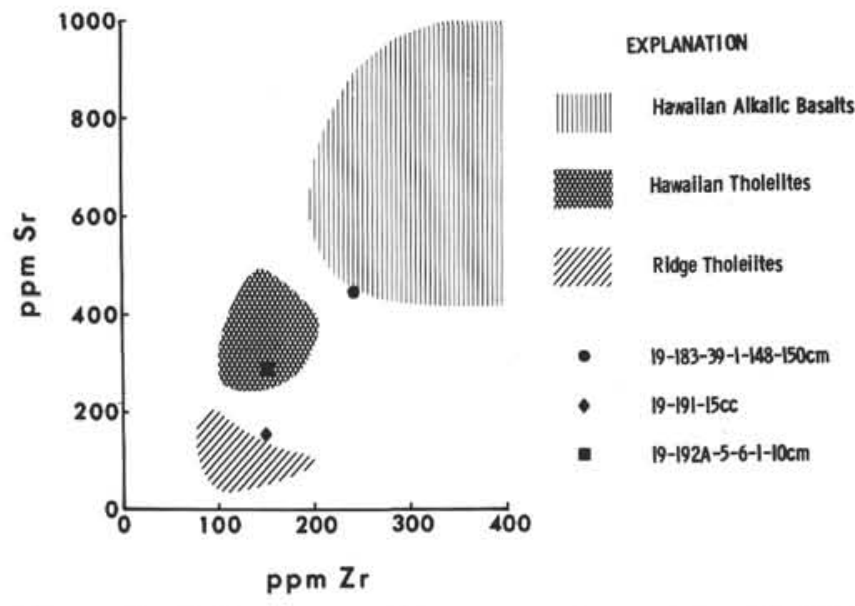

Figure 14. Sr: $\mathrm{Zr}$ diagram illustrating relationship of DSDP Leg 19 basalts to other basaltic provenances (after Hubbard, 1969).

interpretation may account for the discrepancy between the apparent magnetic anomaly ages and the fossil record at this site, since the eruptive phase sampled would be younger than the crust upon which the volcano developed. It also implies that this hole did not bottom out in open-ocean crustal material, but instead on the upper part of a non-ridge submarine volcanic sequence.

The geologic implication of the basalt beneath late Miocene deposits in Kamchatka Basin is difficult to assess. Because reflection records reveal that the mafic layer is regional in extent, but has a gentle but undulating relief, and appears to be buried depositionally, the basalt is not considered to be an intrusive body, a conclusion strengthened by the middle Oligocene K-Ar age of included plagioclase microlites (Table 3 ). 
TABLE 1

Chemical Analyses, Volcanic Rocks

\begin{tabular}{|c|c|c|c|c|}
\hline Sample & & $\begin{array}{l}19-183-39-1 \\
148-150 \mathrm{~cm})\end{array}$ & $\begin{array}{l}19-191-15 \\
\text { (CC) }\end{array}$ & $\begin{array}{c}19-192 \mathrm{~A}-5-6 \\
(1-10 \mathrm{~cm})\end{array}$ \\
\hline \multicolumn{5}{|c|}{ Weight percent doxides ${ }^{a}$} \\
\hline $\mathrm{SiO}_{3}$ & & 45.9 & 47.6 & 47.1 \\
\hline $\mathrm{Al}_{2} \mathrm{O}_{3}$ & & 15.6 & 15.9 & 14.3 \\
\hline $\mathrm{Fe}_{2} \mathrm{O}_{3}$ & & 3.7 & 4.6 & \\
\hline $\mathrm{FeO}$ & & 8.1 & 4.8 & 6.1 \\
\hline $\mathrm{MgO}$ & & 7.7 & 6.0 & 3.8 \\
\hline $\mathrm{CaO}$ & & 8.6 & 10.6 & 7.0 \\
\hline $\mathrm{Na}_{2} \mathrm{O}$ & & 2.9 & 2.8 & 2.4 \\
\hline $\mathrm{K}_{2} \mathrm{O}$ & & 1.2 & 0.23 & 2.0 \\
\hline $\mathrm{H}_{2} \mathrm{O}+$ & & 2.9 & 2.5 & 2.4 \\
\hline $\mathrm{H}_{2} \mathrm{O}$ & & 0.49 & 2.4 & 2.0 \\
\hline $\mathrm{TiO}_{2}$ & & 1.9 & 1.7 & 1.8 \\
\hline $\mathrm{P}_{2} \mathrm{O}^{5}$ & & 0.46 & 0.28 & 0.26 \\
\hline $\mathrm{MnO}$ & & 0.20 & 0.33 & 0.21 \\
\hline \multirow[t]{2}{*}{$\mathrm{CO}_{2}$} & & 0.05 & 0.05 & 1.3 \\
\hline & Total & 100 & 100 & 99 \\
\hline
\end{tabular}

Normative composition (CIPW) ${ }^{\mathrm{b}}$

\begin{tabular}{|c|c|c|c|c|}
\hline Or & & 7.4 & 1.4 & 12.9 \\
\hline $\mathrm{Ab}$ & & 24.3 & 25.0 & 22.1 \\
\hline An & & 27.0 & 31.8 & 24.3 \\
\hline $\mathrm{Ne}$ & & 0.6 & - & - \\
\hline Wo & & 5.9 & 9.1 & 4.6 \\
\hline En & & 3.2 & 12.0 & 12.7 \\
\hline Fs & & 2.6 & 10.2 & 9.4 \\
\hline Fo & & 11.8 & 2.6 & 4.4 \\
\hline $\mathrm{Fa}$ & & 10.6 & 2.5 & 3.6 \\
\hline Mt & & 1.8 & 1.4 & 1.6 \\
\hline Il & & 3.7 & 3.4 & 3.7 \\
\hline \multirow[t]{2}{*}{ Ap } & & 1.1 & 0.7 & 0.7 \\
\hline & Total & 100.0 & 100.1 & 100.0 \\
\hline Sialic & & 59.3 & 58.2 & 59.3 \\
\hline Femic & & 40.7 & 41.8 & 40.7 \\
\hline Di & & 9.1 & 17.9 & 11.7 \\
\hline Di-Wo & & 4.6 & 9.1 & 5.9 \\
\hline Di-En & & 2.6 & 4.8 & 3.2 \\
\hline Di-Fs & & 1.9 & 4.0 & 2.6 \\
\hline $\mathrm{Hy}$ & & 17.7 & 13.4 & - \\
\hline Hy-En & & 10.2 & 7.2 & - \\
\hline $\mathrm{Hy}-\mathrm{Fs}$ & & 7.5 & 6.1 & - \\
\hline 01 & & 8.0 & 5.1 & 22.4 \\
\hline 01-Fo & & 4.4 & 2.6 & 11.8 \\
\hline $01-\mathrm{Fa}$ & & 3.6 & 2.5 & 10.6 \\
\hline Differe & ial Index & 35.0 & 26.4 & 32.3 \\
\hline
\end{tabular}

TABLE 1 - Continued

\begin{tabular}{|c|c|c|c|}
\hline Sample & $\begin{array}{l}19-183-39-1 \\
(148-150 \mathrm{~cm})\end{array}$ & $\begin{array}{l}\text { 19-191-15 } \\
\text { (CC) }\end{array}$ & $\begin{array}{c}19-192 \mathrm{~A}-5-6 \\
(1-10 \mathrm{~cm})\end{array}$ \\
\hline \multicolumn{4}{|c|}{ Minor element conten $\mathrm{t}^{\mathrm{c}}$} \\
\hline $\mathrm{Mn}$ & 1400 & 2200 & 1200 \\
\hline B & $\mathrm{N} 20$ & N20 & $\mathrm{N} 20$ \\
\hline $\mathrm{Ba}$ & 180 & 9 & 60 \\
\hline Co & 48 & 44 & 44 \\
\hline $\mathrm{Cr}$ & 420 & 380 & 120 \\
\hline $\mathrm{Cu}$ & 80 & 80 & 50 \\
\hline Mo & $\mathrm{N} 4$ & N4 & $\mathrm{N} 4$ \\
\hline $\mathrm{Ni}$ & 290 & 95 & 65 \\
\hline $\mathrm{Sc}$ & 40 & 40 & 48 \\
\hline $\mathrm{Sr}$ & 440 & 174 & 280 \\
\hline v & 220 & 290 & 250 \\
\hline $\mathrm{Y}$ & 46 & 50 & 36 \\
\hline $\mathrm{Zr}$ & 240 & 150 & 150 \\
\hline $\mathrm{Ga}$ & 15 & 15 & 15 \\
\hline $\mathrm{Yb}$ & 3 & 6 & 3 \\
\hline $\mathrm{Rb}$ & - & 9 & - \\
\hline Sr $87 / 86$ & - & 0.7024 & - \\
\hline
\end{tabular}

${ }^{a}$ Weight percentages by X-ray fluorescense supplemented by methods described in U. S. Geological Survey Bulletin 1144-A. Analysts, P. Elmore, R. Moore, H. Smith, J. Kelsey, J. Glenn, Rapid Rock Analysis Laboratory, United States Geological Survey, Menlo Park, California.

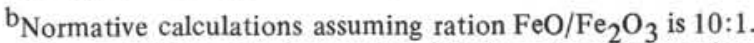
All calculations are dewatered. Calcium content in calculation for sample 19-192A is adjusted for high $\mathrm{CO}_{2}$ content, assuming all $\mathrm{CO}_{2}$ is in calcite.

${ }^{\mathrm{c}} \mathrm{Quantatative}$ spectrographic analysis in parts per million. Results reported to two significant figures with an overall accuracy of \pm 15 percent, except for values near the limits of detection where only one digit is intended. $\mathrm{N}=$ not detected at value shown. Analyst, R. E. Mays, Branch of Analytical Laboratories, United States Geological Survey, Menlo Park, California.

The similarity of the basalt from Site 191 to that of other inter-arc tholeiites is striking. An episode of extensive tectonics within Kamchatka Basin, in response to arc migration (Karig, 1970, 1971; Hart and others, 1972), is certainly implied. We speculate that during modest extension in middle Oligocene time, the basalts may have ingested older Tertiary deposits filling the basin. Models calling for basalt emplacement in response to large-scale extensional rifting or ridge migration (to form the basin) in Oligocene time are conceivable but difficult to harmonize with the structural and tectonic setting of the crustal blocks surrounding the basin, a framework that was largely set up in late Mesozoic and early Tertiary time. It is even more difficult to account for the lack of sediments between late Oligocene and late Miocene times above basalt in a basin so enclosed by presumably actively evolving ridges, (see Cruise Leg Synthesis, Scholl and Creager, this volume). 
TABLE 2

Electron Microprobe Analyses, Selected Volcanic Rocks

\begin{tabular}{|c|c|c|c|c|c|c|c|c|c|c|c|c|}
\hline Sample & $\mathrm{SiO}_{2}$ & $\mathrm{Al}_{2} \mathrm{O}_{3}$ & $\mathrm{FeO}$ & $\mathrm{MgO}$ & $\mathrm{CaO}$ & $\mathrm{Na}_{2} \mathrm{O}$ & $\mathrm{K}_{2} \mathrm{O}$ & $\mathrm{TiO}_{2}$ & $\mathrm{MnO}$ & $\mathrm{NiO}$ & $\mathrm{Cr}_{2} \mathrm{O}_{3}$ & Total \\
\hline \multicolumn{13}{|l|}{ Olivine } \\
\hline $183-39-1(146-148)$ & 39.73 & 0.10 & $14.87 \mathrm{~d}$ & 44.19 & 0.24 & - & - & 0.04 & 0.21 & 0.39 & 0.11 & 99.88 \\
\hline $183-39-1(148-150)$ & 39.63 & 0.18 & $15.52^{\mathrm{d}}$ & 43.20 & 0.26 & - & - & 0.04 & 0.21 & 0.35 & 0.11 & 99.50 \\
\hline \multicolumn{13}{|l|}{ Plagioclase phenocrysts } \\
\hline \multirow[t]{2}{*}{$192 \mathrm{~A}-5-1(116-120)$} & 52.44 & 31.44 & - & - & 13.05 & 3.91 & 0.07 & - & - & - & - & 100.91 \\
\hline & 50.92 & 31.11 & - & - & 14.06 & 3.50 & 0.06 & - & - & - & - & 99.65 \\
\hline \multirow[t]{2}{*}{$192 A-5-2(21-33)^{a}$} & 58.88 & 25.70 & - & - & 8.09 & 7.44 & 0.23 & - & - & - & - & 100.34 \\
\hline & 52.53 & 29.94 & - & - & 13.05 & 4.24 & 0.09 & - & - & - & - & 99.85 \\
\hline \multirow[t]{2}{*}{$192 A-5-6(1-10)$} & 59.90 & 25.52 & - & - & 6.99 & 7.60 & 0.24 & - & - & - & - & 100.25 \\
\hline & 53.65 & 28.65 & - & - & 11.88 & 4.65 & 0.23 & - & - & - & - & 99.06 \\
\hline \multirow{2}{*}{$192 \mathrm{~A}-6-3(72-84)$} & 55.21 & 27.56 & - & - & 10.95 & 5.22 & 0.14 & - & - & - & - & 99.08 \\
\hline & 51.74 & 29.80 & - & - & 13.60 & 3.72 & 0.18 & - & - & - & - & 99.04 \\
\hline \multicolumn{13}{|l|}{ Plagioclase groundmass } \\
\hline \multirow[t]{2}{*}{$192 \mathrm{~A}-5-1(116-120)^{\mathrm{a}}$} & 54.15 & 29.62 & - & - & 11.77 & 4.75 & 0.08 & - & - & - & - & 100.37 \\
\hline & 52.16 & 31.37 & - & - & 12.99 & 3.99 & 0.07 & - & - & - & - & 100.58 \\
\hline \multirow[t]{2}{*}{$192 A-5-2(21-33)^{a}$} & 59.22 & 24.92 & - & - & 7.59 & 7.63 & 0.24 & - & - & - & - & 99.60 \\
\hline & 57.81 & 26.10 & - & - & 8.68 & 7.00 & 0.19 & - & - & - & - & 99.78 \\
\hline \multirow[t]{2}{*}{$192 A-5-6(1-10)$} & 60.64 & 24.60 & - & - & 6.65 & 7.95 & 0.25 & - & - & - & - & 100.09 \\
\hline & 53.99 & 28.63 & - & - & 11.49 & 4.78 & 0.11 & - & - & - & - & 99.00 \\
\hline \multirow[t]{2}{*}{$192 \mathrm{~A}-6-3(72-84)$} & 58.71 & 25.60 & - & - & 8.48 & 6.80 & 0.19 & - & - & - & - & 99.78 \\
\hline & 52.24 & 29.59 & - & - & 13.46 & 3.98 & 0.07 & - & - & - & - & 99.34 \\
\hline \multicolumn{13}{|l|}{ K-feldspar cores } \\
\hline $192 \mathrm{~A}-5-1(116-120)$ & 64.81 & 18.83 & - & - & 0.05 & 0.16 & 16.07 & - & - & - & - & 99.93 \\
\hline $192 \mathrm{~A}-5-6(1-10)$ & 65.06 & 18.19 & - & - & 0.12 & 0.22 & 15.65 & - & - & - & - & 99.12 \\
\hline $192 \mathrm{~A}-6-3(72-84)$ & 65.68 & 17.80 & - & - & 0.09 & 0.14 & 15.98 & - & - & - & - & 99.69 \\
\hline \multicolumn{13}{|l|}{$\begin{array}{l}\text { Clinopyroxene } \\
\text { phenocrysts }\end{array}$} \\
\hline $192 \mathrm{~A}-5-1(116-120)$ & 50.27 & 4.74 & 8.01 & 14.89 & 20.49 & - & - & $1.00^{\mathrm{c}}$ & - & $0.03^{\mathrm{c}}$ & - & 99.43 \\
\hline $192 \mathrm{~A}-5-2(21-33)$ & 50.99 & 4.39 & 8.08 & 14.79 & 20.50 & - & - & 1.11 & 0.30 & 0.03 & 0.07 & 100.26 \\
\hline $192 \mathrm{~A}-5-6(1-10)$ & 51.15 & 4.49 & 9.36 & 13.95 & 19.83 & - & - & 1.28 & 0.30 & 0.03 & 0.08 & 100.47 \\
\hline $192 \mathrm{~A}-6-3(72-82)$ & 50.90 & 4.64 & 8.62 & 14.80 & 19.52 & - & - & 1.19 & 0.28 & 0.03 & 0.13 & 100.13 \\
\hline \multicolumn{13}{|l|}{$\begin{array}{l}\text { Clinopyroxene } \\
\text { groundmass }{ }^{b}\end{array}$} \\
\hline $192 \mathrm{~A}-5-2(21-33)$ & $\begin{array}{c}48.27 \\
(47.10-49.90)\end{array}$ & $\begin{array}{c}4.64 \\
(3.81-5.37)\end{array}$ & $\begin{array}{c}9.79 \\
(8.20-13.19)\end{array}$ & $\begin{array}{l}13.99 \\
(11.47-15.53)\end{array}$ & $\begin{array}{c}20.04 \\
(18.92-21.00)\end{array}$ & - & - & $\begin{array}{c}1.34 \\
(0.90-1.87)\end{array}$ & 0.42 & 0.03 & 0.03 & 98.65 \\
\hline $192 \mathrm{~A}-5-6(1-10)$ & $\begin{array}{c}48.35 \\
(47.76-49.33)\end{array}$ & $\begin{array}{c}4.76 \\
(4.05-5.47)\end{array}$ & $\begin{array}{c}12.06 \\
(9.83-13.42)\end{array}$ & $\begin{array}{l}12.14 \\
(11.16-13.67)\end{array}$ & $\begin{array}{c}19.64 \\
(18.27-20.35)\end{array}$ & - & - & $\begin{array}{c}1.63 \\
(1.31-1.83)\end{array}$ & 0.42 & 0.03 & 0.03 & 99.06 \\
\hline $192 \mathrm{~A}-6-3(72-82)$ & $\begin{array}{c}49.96 \\
(46.64-51.80)\end{array}$ & $\begin{array}{c}4.01 \\
(2.82-6.45)\end{array}$ & $\begin{array}{c}7.83 \\
(7.21-10.28)\end{array}$ & $\begin{array}{l}15.36 \\
(12.95-17.00)\end{array}$ & $\begin{array}{c}20.12 \\
(18.81-20.77)\end{array}$ & - & - & $\begin{array}{c}1.01 \\
(0.75-1.74)\end{array}$ & 0.27 & 0.03 & 0.15 & 98.74 \\
\hline
\end{tabular}

Dashes indicate that values were not determined.

The values given are those of the most sodic and calcic plagioclases encountered.

bValues are the average of a lange number of points; values in parentheses represent the extreme points.

cAssumed.

d Total iron. 


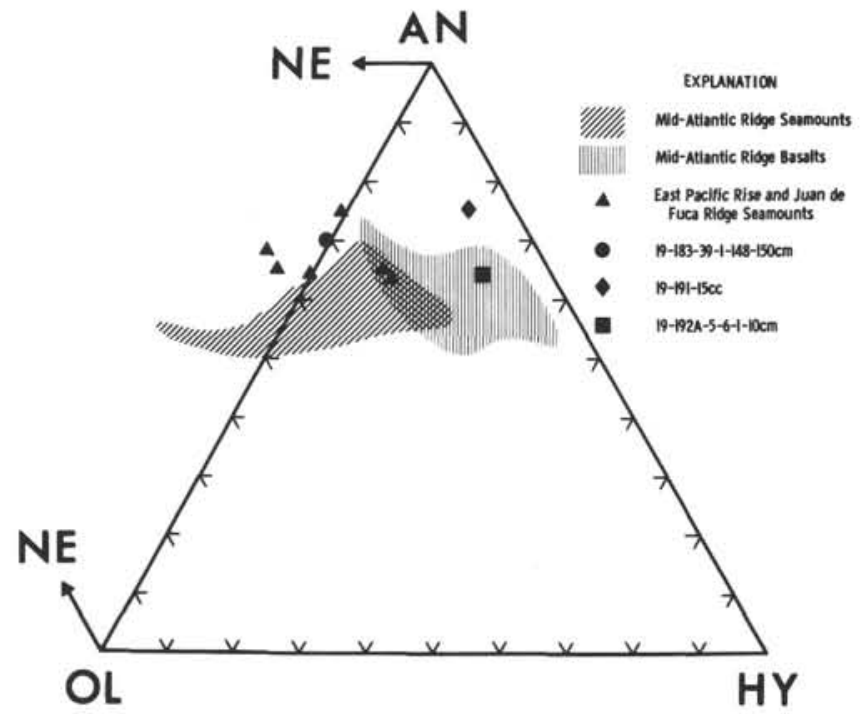

Figure 15. Normative nepheline-plagioclase-olivinehypersthene plot demonstrating the relationship of DSDP Leg 19 basalts to ocean ridge and seamount compositions (after Bass, 1971).

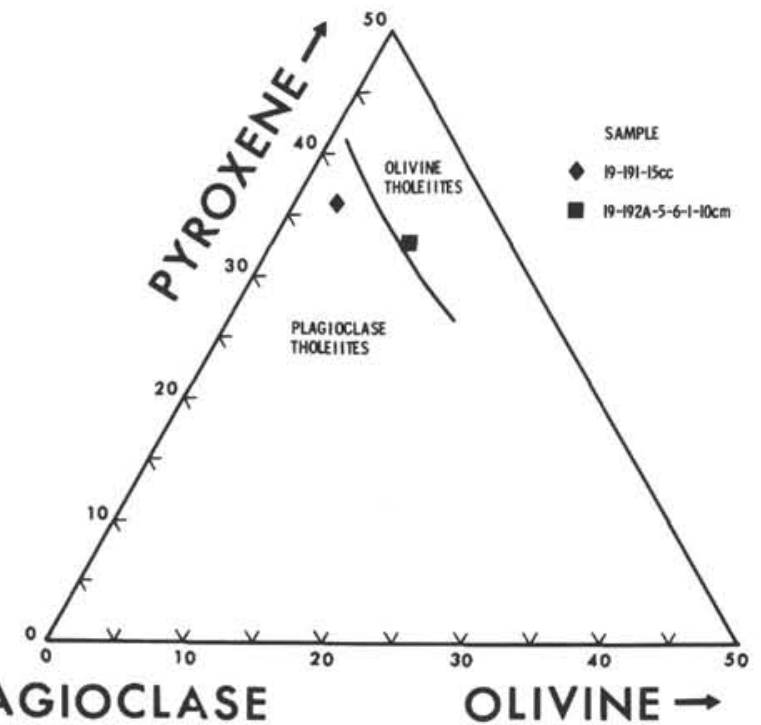

Figure 16. Normative plagioclase-pyroxene-olivine diagram showing basalts from DSDP Sites 191 and 192. Fields of olivine tholeiites and plagioclase tholeiites, after Shido, Miyashiro, and Ewing (1971).

developed. It seems plausible that $\mathrm{Sr}$ and $\mathrm{Ba}$ may have been mobilized along with $\mathrm{Ca}$ and $\mathrm{K}$; whether the fresh rock was

The basalt from Site 192 has a mineralogy typical of alkali basalts, but aspects of its chemistry and its normative classification are more typical of tholeiites. The entire core of basalts has been extensively metasomatized, however, $\mathrm{Ca}, \mathrm{Fe}$, and $\mathrm{K}$ all appear exceedingly mobile since calcite, iron oxides, clays, and secondary $\mathrm{K}$-feldspar are pervasively high or low in these trace elements cannot now be said. Thus, the usual chemical and normative criteria for classifying basalts are essentially useless as far as Site 192 is concerned, leaving the mineralogy the best diagnostic criterion left. On this sole basis, the rocks are tentatively classified as alkali basalts.

The same secondary assemblage of clays, ovoidal calcite, and K-feldspar replacing calcic cores of plagioclase crystals was reported by Bass and others (in press) from tholeiitic basalts of Site 165 from DSDP Leg 17 in the central Pacific. However, there, the tholoeiitic nature of the original basalt is more firmly established. Those authors concluded that entensive alkali and $\mathrm{Ca}$ metasomatism under conditions of high $\mathrm{CO}_{2}$ activity occurred to give the secondary assemblage. They noted that $\mathrm{K}$-feldspar replaces calcic cores of plagioclase in certain evaporite lake deposits under high $\mathrm{CO}_{2}$ activity, and visualized the Site 165 occurrence as a deep-marine equivalent of such a process.

The sharp rimming of some of the K-feldspar cores with plagioclase might, however, be interpreted as a magmatic texture. But magmatic K-feldspar of the composition observed cannot have formed as an equilibrium phase in the basalt. Carmichael (1963) and Seck (1971) demonstrated that any magma crystallizing pure orthoclase must lie on the anorthite-orthoclase join in the Ab-An-Or system for pressures up to $10 \mathrm{~kb}$. Given any significant anorthite component, pure anorthite will also crystallize with orthoclase. Anorthite in any form was not detected in the samples examined. Turning the argument around, in those compositions of the ternary system where plagioclase and $\mathrm{K}$-feldspar are in equilibrium, the $\mathrm{K}$-feldspar that should crystallize with plagioclase of composition An65 such as seen at Site 192 should be far more sodic, $\mathrm{Ab}_{10-20} \mathrm{Or}_{90-80}$, than observed. Carmichael (loc. cit.) also concluded that rock series differentiating from a basaltic parent without sialic crustal contamination are single feldspar series only, containing a plagioclase series with no parallel development of potassic sanidines. Single feldspar (plagioclase) rock series typify alkalic series of oceanic islands, of which Meiji Guyot is a likely representative. Possibly, though, the K-feldspars are xenocrysts scavenged from late-stage plutonic activity on such an island. However, their total absence in the chilled glass margins, the development of very irregular boundaries to the potassic cores in some cases, and occasional relict plagioclase "floating" in the K-feldspars are all evidence for a secondary rather than a xenocrystal origin. The very sharp zonation developed in Figure 10 can still be interpreted as magmatic, but the inner zone, once calcic plagioclase, has been completely replaced by potash sanidine. The high alkalinities and salinities necessary for the intense formation of K-feldspar alteration and may be attributed to solution and hydrolysis of vitric material in the altered variolitic and diabasic portions. Relative lack of alteration and replacement in the glassy margins could be permeability controlled; glassy zones are perhaps impervious to secondary solutions, whereas crystalline portions allow more even circulation.

\section{REFERENCES}

Bass, M. N., 1971. Variable abyssal basalt populations and their relation to sea-floor spreading rates. Earth Planet. Sci. Lett. 11, 18. 


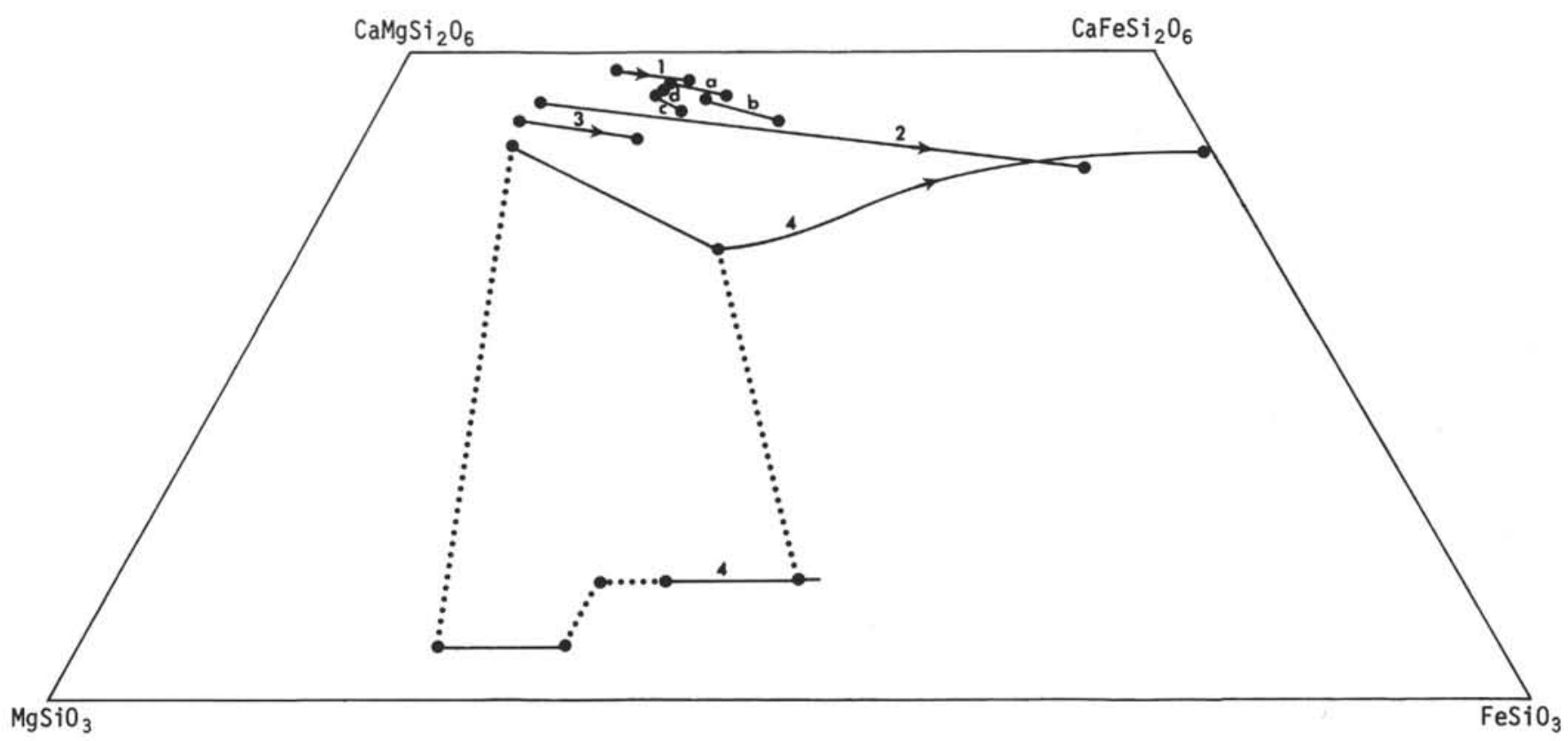

Figure 17. Clinopyroxenes, Cores $192 A-5$ and 6. End points connect phenocrysts (left) and average ground-mass (right). Trends shown are (1) the Black Jack Teschenite (Wilkinson, 1957); (2) the alkali basalt-trachyte series, Japan (Aoki, 1964); (3) Gough Island Alkalic Series (LeMaitre, 1962); (4) the Skaergard Series (Brown and Vincent, 1963). (a) Sample 192A-5-2(21-33); (b) Sample 192A-5-6(1-10); (c) Sample 192A-6-3(72-84); and (d) Sample 192A-5-1(116-120).

TABLE 3

Feldspar and Whole-Rock Isotopic Ages, Basalt, Site 191

\begin{tabular}{|c|c|c|c|c|c|c|}
\hline $\begin{array}{l}\text { Laboratory } \\
\text { Sample \# }\end{array}$ & $\begin{array}{c}\text { Field } \\
\text { Sample \# }\end{array}$ & $\begin{array}{c}\text { Isotopic } \\
\text { Age (m.y. })^{a}\end{array}$ & $\operatorname{scc~Ar} 40 \mathrm{Rad}_{/ \mathrm{gm}} \times 10^{-5}$ & $\% \mathrm{Ar}^{40} \mathrm{Rad}$ & $\% \mathrm{r}$ & \\
\hline \multirow[t]{2}{*}{$\begin{array}{l}\text { KA 72-214 } \\
\text { Plagioclase }\end{array}$} & \multirow[t]{2}{*}{$\begin{array}{l}19-191-16-1 \\
(93-107)\end{array}$} & - & \multirow[t]{2}{*}{0.0023} & 1 & \multirow{2}{*}{\multicolumn{2}{|c|}{$\begin{array}{l}0.23 \\
0.17 \\
0.20\end{array}$}} \\
\hline & & 32.3 & & 11 & & \\
\hline KA $72-129$ & $19-191-16-1$ & 35.6 & 0.00144 & 1 & & 0.01 \\
\hline \multirow[t]{2}{*}{ Plagioclase } & $(116-123)$ & 28.6 & 0.00576 & 5 & & 0.05 \\
\hline & & Ave. & 0.0036 & - & & 0.03 \\
\hline KA $72-129$ & & 16.5 & 0.0212 & 23 & & 0.32 \\
\hline
\end{tabular}

Bass, M. N., Moberly, R. M., Rhodes, J. M., and Shih, C. in prep. Volcanic Rocks, Leg 17. In Winterer, E. L., Ewing, J. I., et al. Initial Reports of the Deep Sea Drilling Project, Volume XVII. Washington (U.S. Government Printing Office).

Bass, M. N., Moberly, R. M., Rhodes, J. M. and Shih, C., in prep. Volcanic Rocks, Leg 17. In Winterer, E. L., Ewing, J. I. et al. Initial Reports of the Deep Sea Drilling Project, Volume XVII. Washington (U. S. Government Printing Office).

Carmichael, I. S., 1963. The crystallization of feldspar in volcanic acid glass. Geol. Soc. London Quart. J. 119, 95.

Engel, A. E., Engle, C. G., and Havens, R. G., 1965. Chemical characteristics of oceanic basalts and the upper mantle. Bull. Geol. Soc. Am. 76, 719.
Erickson, B. H. and Grim, P. J., 1969. Profiles of magnetic anomalies south of the Aleutian Island arc. Bull. Geol. Soc. Am. 80, 1387

Fodor, R. V. and Bunch, T. E., 1972. Mineral chemistry of rocks from Maui, Hawaii: pyroxenes. In Abst. w. prog., Geol. Soc. Am. 68th Ann. Mtgs. Cordilleran Section, p. 158.

Garrison, R. E., 1972. Inter- and intrapillow limestones of the Olympic Peninsula, Washington. J. Geol. 80, 310.

Grim, P. J., 1969. Seamap deep-sea channel: ESSA Tech. Rept., ERL 93 - Pol 2, Seattle, Washington, P. 1.

Hamilton, E. L., 1967. Marine Geology of abyssal plains in the Gulf of Alaska. J. Geophys. Res. 72, 4190.

, in press. Marine Geology of the Aleutian Abyssal Plain. Marine Geology. 
Hart, S. R., Glassley, W. E., and Karig, D. E., 1972. Basalts and sea floor spreading behind the Mariana Island Arc. Earth Planet. Sci. Lett. 15, 12.

Heirtzler, J. K.; Dickson, G. O., Herron, E. M., Pitman, W. C., and Le Pichon, X., 1968. Marine magnetic anomalies, geomagnetic field reversals, and motions of the ocean floor and continents. J. Geophys. Res. 73, 2119.

Hubbard, N. J., 1969. A chemical comparison of oceanic ridge,. Hawaiian tholeiitic and Hawaiian alkalic basalts. Earth Planet. Sci. Lett. 5, 346.

Karig, D. E., 1970. Ridges and basins of the TongaKermadec Island arc system. J. Geophys. Res. 75, 239. , 1971. Origin and development of marginal basins in the Western Pacific. J. Geophys. Res. 76, 2542.

Kuno H., 1960. High alumina basalt. J. Petrology. 1 (pt. 2), 121 .

1968. Differentiation of basalt magmas. In Basalts; the Poldervaart Treatise on Rocks of Basaltic Composition. H. H. Hess and A. Poldervaart (Eds.). New York (Interscience). Vol. 2, 267.
MacDonald G. A. and Katsura, T., 1964. Chemical composition of Hawaiian lavas. J. Petrology. 5, 82.

Mammerickx, J., 1970 Morphology of the Aleutian Abyssal Plain, Bull. Geol. Soc. Am. 81, 3457

Sclater, J. G., Hawkins, J. W.; Mammericks, J.; and Chase, C. G., 1972. Crustal extension between the Tonga and Lau ridges: petrological and geophysical evidence. Bull. Geol, Soc. Am. 83, 505.

Seck, J. A., 1971. Der einflub des drucks auf die zusammensetzung koexistierender alkalafeldspare und plagioclase in system NaA $1 \mathrm{Si}$, 08-KalSi $308-\mathrm{CaAl}_{2} \mathrm{Si}_{2} 08-\mathrm{H}_{2}$ ). Contrib. Mine. Petrology. $31,67$.

Shido, F., Miyashiro, A., and Ewing, E., 1971. Crystallization of abyssal tholeiite. Contrib Mine. Petrology. $31,251$.

Vance, J. A., 1969. On Synneusis. Contrib. Mine Petrology. 24,7 .

Wilson, M. E., 1960. Origin of pillow structure in early Precambrian lavas of western Quebec. J. Geol. 68, 97. 